\title{
Citation and Distortion: Pierre Pomme, Voltaire and the Crafting of a Medical Reputation
}

Sabine Arnaud

\section{Summary}

In his Questions sur l'Encyclopédie Voltaire casts Doctor Pierre Pomme as an exorcist for modern times. For the philosopher, Pomme's treatment of hysteric and hypochondriac affections exemplifies the struggle against fanaticism and ignorance. In subsequent private correspondence Pomme and Voltaire exchange letters built around Christian metaphors. The term "exorcist" evokes a series of images putting into play the status of Pomme and the discipline of medicine as a whole. This article analyses the figurative schemes developed by Pomme and Voltaire, and how the use of metaphors generates a myth of therapy. It examines how Pomme seizes upon the rhetoric employed to create an image of his role as a doctor while also pursuing strategic aims particular to his work.

Keywords: Voltaire; Pierre Pomme; rhetoric; 18th century; hysteric and hypochondriac affections; religious imaginings; metaphors

Across readings and rereadings of the eighteenth century Voltaire is recurrently cited as the standard bearer of the Enlightenment and its critical spirit ${ }^{1}$. His sharp irony and scathing language are considered emblematic of the time's desire to demystify established knowledge and traditions. Voltaire

1 Portions of this work were presented at the Twelfth International Enlightenment Congress "Knowledge, Techniques and Cultures in the Eighteenth Century", held in Montpellier in 2007, and at the meeting of ACUME II, Interfacing Sciences, Literature and Humanities, organised by Jean Bessière at the Sorbonne-Paris III. I would like to thank the organisers of the conferences along with Anne Vila and Peter Cryle.

Sabine Arnaud (Texas A\&M University), ICI Berlin, Christinenstrasse 18-19, Haus 8, D-10119 Berlin (sabine_arnaud@yahoo.com). 
incorporated discussion of numerous political and religious conflicts in his satires. One is left wondering how these commentaries were read by Voltaire's own contemporaries. Did any of them risk playing on the words of Voltaire? Were his own writings ever instrumentalised? This article thus reverses the customary direction of inquiry, analysing how texts by Voltaire himself were reinvested by exterior rhetorical manipulation. The writer in question here was neither a man of letters nor a philosopher. Instead, he practised a profession often scorned in the eighteenth century for purported lack of competence and shallowness of discourse: he was a doctor. Pierre Pomme was born in Arles, studied medicine in Montpellier and went on to become a doctor to King Louis XV, before recasting himself as a defender of the French Revolution. This article examines how Pomme capitalised on Voltaire's views on his medical practice and redirected them for his own benefit, constructing his reputation through the skillful citation of a few words from the philosopher.

Pierre Pomme ${ }^{2}$ has long ago disappeared from the annals of medicine's celebrated doctors. Yet in the eighteenth century Pomme enjoyed unprecedented success following the publication of Traité des affections vaporeuses des deux sexes: ou Maladies nerveuses, vulgairement appelées maux de nerfs. Initially published in 1760 , the treatise was republished with additional material in 1765 and 1767, published in two volumes in 1769, with additions in 1771 and in quarto pages accompanied by an engraving of the author in 1782. A new edition published in the revolutionary calendar year VII spread to three volumes in 1804 . The work was also published in Italian in $1765^{3}$, in German in $1775^{4}$, in English in $1777^{5}$ and in three Spanish editions before the century's close ${ }^{6}$. These incessant republications were met with an outburst of criticism. As early as 1763, an anonymous work appeared discussing Pomme's treatise with an enormous amount of sarcasm ${ }^{7}$. Pomme entered into

2 Born in 1728, Pierre Pomme graduated from the Montpellier School of Medicine on August 10, 1747. In 1767, he was given the titles of Consulting doctor of the King and Grand Falconer, which he would retain until the Revolution. By way of exception these positions allowed him to practise in the area of Ile-de-France without living in the region. On June 30, 1803, he was received by the Academic Society of Sciences of Paris. He died on April 7, 1814. For further biographical information on Pierre Pomme, see Aubert 1998. The biographical dates provided for Pomme are subject to several variations. Those offered here are given by the Departmental Encyclopaedia of the Bouches-du-Rhône, from the volume "biographies", which provides the dates June 5,1728-April 7, 1814. The article is signed by Emile Fassin.

3 Pomme, Naples, 1765.

4 Pomme, Breslau, 1775.

5 Pomme, London, 1777.

6 Pomme, Madrid, 1776, 1786, 1794.

7 The trend begins with an anonymous work that appears in 1763, followed by works by Rostaing (1767), Jean-Baptiste Chevalier (1772) and Louis Bret (1806). 
dialogue with this variety of critique and even encouraged it. A polemic in the Journal de Médecine $e^{8}$ followed shortly thereafter, and the doctor began publishing these attacks within new editions of his treatise that responded to his rivals and added new accounts of successful cures. By giving a forum to his adversaries, he acted as though the controversy were a matter in the public interest and positioned the treatment of the vapors at the centre of medical practice.

Such a storm of debate around the vapors is fueled in part by their fashionability during this period. Many doctors regarded the affliction as the most prevalent of all illnesses ${ }^{9}$. Up until the French Revolution, the vapors were the most frequently diagnosed malady among aristocrats, though they were also identified regularly in the population at large ${ }^{10}$. A slew of medical treatises were devoted to the malady. Its diagnosis encompassed a host of symptoms, including headaches, crying, convulsions and fainting. Doctors' explanations of the illness ranged widely, variously identifying the origin of troubles in the womb, brain, fibres, worms, sensibility or imagination. Pomme's Traité des affections vaporeuses des deux sexes: ou Maladies nerveuses, vulgairement appelées maux de nerfs presents readers with a new approach to the illness. For Pomme conditions of suffering, convulsion and paralysis are all caused by a hardening of fibres related to a dryness of the body. They may be caused by hysteric or hypochondriac maladies or can be an effect of taking popular tonic remedies such as quinine. To treat these conditions, he recommends taking cold baths that can last between two and ten hours each day, moderate bleedings and drinking litres of chicken, veal and frog broth.

8 On the subject of polemics that developed in the Journal de Médecine around the works of Pierre Pomme, see Wenger 2009.

9 One repeatedly finds this affirmation in French and English medical writings over the course of the eighteenth century. Richard Blackmore writes: "Of all the Chronical Distempers that afflict the Body, or disturb the Mind, these two, Consumptions and the Spleen, are in this Kingdom the most rise and prevalent; and either directly by their own Power, or by introducing other Diseases, make the greatest Havock and Destruction among the People." Blackmore 1725, 2. Referencing Sydenham, Joseph Raulin writes: "One has noticed that vapors are already more than half of all chronic maladies, that day by day they extend their empire. Women are not the only ones to be afflicted, they have also asserted their rights over men." [All translations into English by Sabine Arnaud and Brian Price.] ["On a remarqué que les vapeurs sont déjà plus de la moitié des maladies chroniques, qu'elles établissent de jour en jour un empire plus étendu. Les femmes ne sont pas les seules qui s'affligent, elles ont aussi acquis des droits sur les hommes."] Raulin 1758, 3. And Joseph Lieutaud affirms peremptorily: "Nothing is more common than hysteric affection; there are few but the women who lead a laborious life that are exempt from it." [«Rien n'est plus commun que l'affection hystérique; il n'y a guère que les femmes qui mènent une vie laborieuse qui en soient exemptes.»] Lieutaud 1781, 394.

10 On the subject of court doctors, see Chaussinand-Nogaret 1977. On the role of rhetoric in the sciences, see Shapin 1994. 
Eighteenth-century medical treatises on the vapors employ a variety of literary strategies, using the formats of dialogue ${ }^{11}$ and correspondence. Doctors craft their works mindful of their reception in a lettered milieu ${ }^{12}$. Unlike many of his colleagues, Pomme does not linger on the findings of renowned doctors and instead opts to list his famous patients ${ }^{13}$.

Though the writing strategies of observation and polemics are not new to medicine, Pomme extends them to an unforeseen degree. His treatises focus on the narration of cures he has performed. Such a practice of recording cases existed in antiquity, e.g. in the Hippocratic writings, and developed widely in the eighteenth century. While many doctors kept case books, they often remained unpublished ${ }^{14}$. When they were published, case histories were generally narrated only so as to justify a diagnosis. Doctors discussed indirect causes (social milieu, education, lifestyle) and direct causes (the circumstances immediately surrounding the commencement of the affection), and granted much space to the spectacle and singularity of hysteric crisis ${ }^{15}$. Pomme, however, rapidly passes over these aspects. He instead specifies whether patients were unsuccessfully treated by other doctors and then details the stages of his own treatments. His treatise exhaustively traces the path he follows with patients, day after day, month after month, monitoring their progress, their relapses and struggles he witnesses at their side. He dwells upon physical reactions that attest to the benefits of his prescribed therapies. Whereas most doctors devote the bulk of their writing to proving their understanding the causes of the malady, Pomme utilises observations to emphasise his triumph. Observations constitute almost the entirety of his work, with rare moments of theoretical reflection subsumed inside case narratives. Pomme constantly contrasts his successes with the fruitless treatments of his colleagues. His writing centres upon individual cases, rendered with evocative imagery. The focus on results rather than comprehension of the illness aims to convince prospective patients at least as much as fellow doctors. Pomme displaces emphasis from the malady itself and emphasises his patented therapies, seizing upon the surrounding polemics to dramatise his discourse.

11 Hunauld 1756.

12 See Arnaud 2007; Wenger 2007. On strategies for professional success in the medical sphere, see Roche 1977; Siraisi 1990; Siraisi 1991; Tribby 1991; Porter 1992; Findlen 1993; Jordanova 1999; Jordanova 2000; Barras/Louis Courvoisier 2001.

13 Notably Madame de Belzune, Madame de Cligny, Monsieur de la Roquette, Madame de Bezons.

14 See notably Lockwood 1951; Duden 1987; Nance 2001.

15 See Cheyne 1733; Chirac/Silva 1740; Raulin 1758; Pressavin 1770; among others. 
The use of polemics, customarily associated with charlatans and empirics, is not unknown to doctors ${ }^{16}$. Yet Pomme's work is singular in that it places polemics at the centre of debates on therapeutics ${ }^{17}$. In the past, polemical works tended to operate as a territory annexed to knowledge, a space of purely rhetorical dispute. With Pomme the use of rhetoric appears inseparable from the invention and formulation of knowledge. Polemics become a perpetual practice, constantly reactivating the furor of colleagues. Pomme understands the necessity of reworking the public's perception of medicine. Rather than contesting the common vision of doctors as criminal and incompetent, Pomme uses these impressions in order to establish his own career. A minor dispute between colleagues would fall short of inaugurating a new vision of medicine. Controversy is instead placed at the very heart of the text, giving it its raison d'être; or, in eighteenth century parlance, giving it its nerve. Pomme's extravagance functions to confirm his authority. To convey the stakes at play in his writing, he adopts a tone both lyrical and severe. His treatise hurries his audience into deciding their allegiance, demanding a partisan reading. Endless polemics and publications position Pomme in a unique role. When other doctors contest his methods, they are only confirming his singularity.

The circulation of Pomme's treatise was bolstered by the controversy surrounding it, and it eventually came to attract the interest of Voltaire ${ }^{18}$. Voltaire references Pomme in his Questions sur l'Encyclopédie, casting him as an exorcist for modern times. For the philosopher, Pomme's treatment of hysteric and hypochondriac affections exemplifies the struggle against fanaticism and ignorance. In the private correspondence that follows, Pomme and Voltaire exchange letters built around Christian metaphors. The term "exorcist" evokes a series of images in which the status of both Pomme himself and the discipline of medicine are at stake. This article analyses the figurative schemes developed by Pomme and Voltaire, considering how the use of metaphors gives rise to a myth of therapy. It examines how Pomme uses the rhetoric

16 On the similarity of practices between medical school graduates and empirics, see Brockliss/ Jones 1997, 622-670; Ramsey 1988.

17 Cunningham 1981; Harley 1990; Harley 1999; Siraisi 1990; Findlen 1993. The late seventeenth century in particular was marked by a dispute between two celebrated doctors to the King, Raymond de Vieussens and Pierre Chirac, who accused each other of plagiarism and immorality. Vieussens claimed that he for a long time resisted responding to Chirac's attacks for fear that polemics would distract him from accomplishing his own work.

18 Pomme is not the only doctor to have been mentioned by Voltaire. The philosopher also maintained correspondence with Samuel-Auguste Tissot and Théodore Tronchin. These latter doctors attracted the admiration and scorn of their colleagues for their enormous success in aristocratic milieus and their "self-fashioning". Attesting to their notoriety, Tissot was mentioned by Kant and Rousseau, among others, while Tronchin was mentioned by Diderot and Voltaire. In this regard, cf. notably Voltaire 1950; Eynard 1839; Vila 2002. 
employed as an occasion to create an image of his role as a doctor while pursuing the strategic aims particular to his work.

Voltaire's Questions sur l'Encyclopédie, published in nine volumes between 1770 and 1772, accords Pomme a position of prestige in the entry "The Great Exorcist":

The Possessed, the maniacs, the exorcised, "or, more exactly" those made sick by their womb or chlorosis, hypochondriacs, epileptics, cataleptics, all those cured by the emollients of Mr. Pomme, the Great Exorcist

The vaporous, the epileptics, and women tormented by their uterus, are said to be the victims of malignant spirits, evil demons, and the gods' vengeance. We have seen these pains called sacred sickness, and the priests of Antiquity took possession of these maladies, since the doctors of the time were completely ignorant.

When symptoms were complicated, it was said that one had many demons in the body, one demon of furor, one of lust, one of contraction, one of tautness, one of bedazzlement, one of deafness; and surely, the exorcist himself had demons of absurdity and mischief. ${ }^{19}$

By treating as illness what had long been considered demonic possession, Pomme echoes the Enlightenment goal of moving from superstition. Voltaire bypasses more celebrated doctors such as Willis and Sydenham, describing Pomme as a New Exorcist armed with an original arrangement of techniques: bathing, broths and bleeding. His work contributes to a new construction of knowledge through its affirmation that hysteric maladies are physiological and rooted in the body. The past denomination of demons is rejected, replaced by a theory on the mechanics of the body. Beelzebub and Astaroth have been relegated to an illusionary world. Voltaire pursues his analogy, rewriting the story of Saint Paulin:

This saint saw upon the arch of a church a poor demoniac who walked under or above this arch, the head below and the feet in the air, somewhat like a fly. Saint Paulin saw that this man was possessed, he sent others to search some leagues away for the relics of Saint Felix of Nole: he applied these to the patient like vesicatories. The demon who held this man against the arch quickly took flight, and the demoniac fell to the cobblestones below. ${ }^{20}$

19 «Possédés du démon, énergumènes, exorcisés, 〈ou plutôt〉 malades de la matrice, des pales couleurs, hypocondriaques, épileptiques, cataleptiques, guéris par les émollients de M. Pomme, Grand exorciste

Les vaporeux, les épileptiques, les femmes travaillées de l'utérus, passèrent toujours pour être les victimes des esprits malins, des démons malfaisants, des vengeances des dieux. Nous avons vu que ce mal s'appelait le mal sacré, et que les prêtres de l'antiquité s'emparèrent partout de ces maladies, attendu que les médecins étaient de grands ignorants.

Quand les symptômes étaient fort compliqués, c'est qu'on avait plusieurs démons dans le corps, un démon de fureur, un de luxure, un de contraction, un de roideur, un d'éblouissement, un de surdité; et l'exorciseur avait à coup sûr un démon d'absurdité joint à un de friponnerie.» Voltaire 1978, 336.

20 «Ce saint vit à la voûte d'une église un pauvre démoniaque qui marchait sous cette voûte ou sur cette voûte, la tête en bas et les pieds en haut, à peu près comme une mouche. Saint Paulin vit bien que cet homme était possédé; il envoya vite chercher à quelques lieux de là des reliques de saint Felix de Nole: on les appliqua au patient comme vésicatoires. Le démon, qui soutenait cet homme contre la voûte, s'enfuit aussitôt, et le démoniaque tomba sur le pavé.» Voltaire 1978, 336. 
We can now question this story while conserving the utmost respect for real miracles; and it permits us to affirm that we no longer heal demoniacs in this manner. Today, we bleed them, we bathe them, we gently purge them, we give them emollients; that is how Mr. Pomme treats them; and he has performed more cures than the priests of Isis and Diane, and the others who never performed miracles. ${ }^{21}$

With this passage Voltaire lifts an episode from religious history and reduces it to the level of anecdote. His tone affects naiveté and credulity. The hagiography is divested of its authority. Pursuing his attack on superstition, Voltaire recounts the test of floating, for a long time used by religious authorities for those suspected of demonic possession:

It often happened that epileptics had withered fibres and muscles that weighed less than an equivalent volume of water, and that they floated when put in a bath. One cried: Miracle! One said: They are possessed or a witch; and one went searching for holy water or an executioner. It served as unquestionable proof, either that a demon controlled their bodies, or that they had given themselves over to the demon. In the former case they were exorcised, and in the latter case they were burned.22

The test of floating can now be reread in the light of Pomme's experiences with bathing his patients. His medical treatise states that a loosening of tissue leads the body to weigh more and sink to the bottom of the tub ${ }^{23}$. Floating becomes an indication of the hardening of nerves, signalling hysteric or hypochondriac pathology.

After reading "The Great Exorcist", Pomme seizes upon Voltaire's practice of employing religious terms to negate their meaning. He begins to cast his work in a theological framework, while undoing the irony of Voltaire's writings:

Yes Sir, I heal the demoniacs, I return sight to the blind; I allow the lame to walk; I resuscitate the dead; and I proclaim to the entire world the simple manner in which I perform these miracles; however, I have not yet succeeded in curing the hard-headed, the fanatics, and the doctors devoid of faith; it is towards this miracle that I now must work [...]. I had lost faith completely; but I now feel my courage returning to me after reading your encyclopedia; when

21 «Nous pouvons douter de cette histoire en conservant le plus profond respect pour les vrais miracles; et il nous sera permis de dire que ce n'est pas ainsi que nous guérissons aujourd'hui les démoniaques. Nous les saignons, nous les baignons, nous les purgeons doucement, nous leur donnons des émollients: voilà comme M. Pomme les traite; et il a opéré plus de cures que les prêtres d'Isis et de Diane, ou autres, n'ont jamais fait de miracles.» Voltaire 1978, 336.

22 «Il arrivait souvent que des épileptiques ayant les fibres et les muscles desséchés pesaient moins qu'un pareil volume d'eau, et surnageaient quand on les mettait dans le bain. On criait: Miracle! On disait: C'est un possédé ou un sorcier; on allait chercher de l'eau bénite ou un bourreau. C'était une preuve indubitable, ou que le démon s'était rendu maître du corps de la personne surnageante, ou qu'elle s'était donnée à lui. Dans le premier cas elle était exorcisée, dans le second elle était brûlée.» «Démoniaques», Voltaire 1978, 336f.

23 Following this reasoning, Pomme explains the case of many patients like Madame de Cligny: "If the patient has floated for two months, it is because it has taken such time for the water to penetrate and restore to the body its first weight." «Si la malade a surnagé pendant deux mois, c'est parce qu'il a fallu tout ce temps à l'eau pour pénétrer et pour restituer au corps son premier poids.» Pomme 1782, 101-104. 
I see you celebrating my miracles, I feel the desire to return to my work. I will use my feather pen to attack the perverse sect that is the enemy of truth and all that is good. ${ }^{24}$

While Voltaire associates Pomme's therapies with exorcisms as a part of his attack on religion, Pomme views the connection as a sign of prestige. Pomme appropriates theological imagining by expanding upon Voltaire's metaphors, in a manner that amplifies its details and images. Rather than limiting himself to the figure of the exorcist, Pomme evokes the image of Christ, healing the lame and the blind. And instead of using the term "miracle" with critical distance, he restores the signification of the word and recovers its power. Voltaire's affected gullibility derisively unhinges the meaning of the Word, dissolving its pretension to truth while retaining references to its history. Pomme, on the other hand, imports the original significations of terms while removing them from their context, repeating them in a grandiloquent style proper to the narration of miracles. A true subversion of religious discourse emerges, and one can well imagine that Pomme's response must have amused Voltaire. Pomme lowers religious authority to the level of polemics and links the mysteries of the gospel with simple medical practices. His identification with religion functions to reduce theology to a world devoid of transcendence. The exchange between Pomme and Voltaire continues, and on June 27, 1771, Voltaire writes to Pomme from his exile in Ferney:

Madame Racle, who lives in this wilderness and has long been possessed by the same demon as haemorrhage, has not yet been healed by your liquids; but such demons take time to be chased away, and I still believe you to be a great exorcist.

I know that in your path you will encounter scribes and Pharisees who will endeavor to disparage your miracles; but no matter what they say, your kingdom is of this world. As for me, I am possessed by a demon that makes my eyes as red as the touring festivals in the almanacs and nearly deprives me of my sight; yet I will force myself to read all that you write against the enemies of your doctrine with the greatest pleasure. I have faith in your gospel, though the people of my age remain difficult to persuade..$^{25}$

24 «Oui, Monsieur, je guéris les démoniaques, je rends la vue aux aveugles; je fais marcher les boiteux; je ressuscite les morts; et j'apprends à tout l'univers la manière simple d'opérer les merveilles; mais je n'ai pu parvenir encore à guérir les entêtés, les fanatiques et les médecins de mauvaise foi; et c'est là le miracle qu'il faudrait opérer [...]. J'en avais entièrement perdu l'espoir; je sens aujourd'hui mon courage se ranimer, en lisant votre encyclopédie; quand je vous entends célébrer mes miracles, vous me donnez envie d'en faire. Je reprendrai donc la plume pour attaquer cette secte perverse, ennemie du vrai, pour ne dire de tout bien.» Pomme's response reprinted in the Journal Encyclopédique, 463, letter from Pomme to Voltaire.

See manuscripts of Abbé Bonnemant, Extrait des singularités historiques, littéraire, politiques et sacrées et prophanes de la ville d'Arles, tome 225, $1^{\mathrm{re}}$ partie, 49 (Library of the City of Arles).

25 «Madame Racle, Monsieur, qui habite dans mon désert et qui est possédée depuis longtemps du même démon que l'hémorroïsse, n'est pas encore guérie par vos délayants; mais ces sortes de démons ne se chassent qu'avec le temps et je vous tiens toujours pour très bon exorciste. Je crois bien que vous rencontrerez dans votre chemin des scribes et des pharisiens qui tacheront de décrier vos miracles; mais quoiqu'ils fassent, votre royaume est de ce monde. Pour moi, je suis possédé d'un démon qui me rend les yeux aussi rouges que les fêtes mobi- 
Voltaire evokes the miracle of a woman whose haemorrhaging ceased after she touched Christ's garments and goes on to spin a series of metaphors ${ }^{26}$. The terms of miracle, Pharisee, demon and gospel extend the parallels established following Questions sur l'Encyclopédie. Pomme writes back immediately, maintaining his identification with Christ:

What must be done to convert the unbelievers? ... Miracles! Yet those that Jesus Christ performed before Israel angered the Jews, who crucified him rather than converting. I was about to suffer the same fate in Paris and Lyon, as everyone knows. Like these determined Jews, doctors will then never convert or not convert until the world is at its end. ${ }^{27}$

Rather than questioning Voltaire's use of theology, Pomme continues to interpret religious associations as a sign of prestige. By adopting an apocalyptic tone, he transcends polemics with his colleagues. Pomme brandishes religious imagery to embellish his practices. His stubbornness becomes devotion, and his writings become gospel. Metaphors allow the transfer of an aura around Pomme, through signs he borrows from religious history. $\mathrm{He}$ begins to present himself as a savior who brings the dead back to life, clashing with masses of infidels who will stop him at any cost. Every circumstance becomes a pretext for employing religious language. In the 1782 edition of his treatise Pomme states that following his departure from Paris, a public notice in Amiens reported that he had expatriated, while a bulletin in Bordeaux declared that he had died. The doctor incorporates these reports into the preface for the subsequent edition of his work, in which Voltaire is also cited ${ }^{28}$. Pomme also relates Voltaire's comparison in a letter he writes to the Marquis de Grimaldi, published as part of the sixth edition of his treatise:

The news you have heard is not without foundation; for I am in fact mad; how could I not be, as I take it upon myself to correct doctors, preaching morals contrary to their beliefs. For them, this is a new religion, and we all know what happened to the apostles who preached the word of Christ. As such, one must suppose either that my zeal is truly apostolic or that I am mad. Voltaire wrote to me from Ferney, asking my advice on the illness of Madame Racle, attacked by a loss of blood that he compared to the sufferer of Jerusalem. He said that no matter how difficult it is to persuade others, he believes in my gospel; that in my path I would

les dans les almanachs et qui m'ote presque entièrement la vue; mais je me ferai lire avec grand plaisir tout ce que vous écrirez contre les ennemis de votre doctrine. J'ai de la foi à votre évangile, quoique les gens de mon âge soient difficiles à persuader.» Voltaire 1986, 423. See also the letter from Pomme to the Marquis de Grimaldi (Editor's note).

26 The Gospel of Luke, New Testament, Chapter III, Verses 43-48.

27 «Que faudra-t-il donc pour faire convertir nos incrédules? Des miracles! Mais ceux que Jésus-Christ faisait à la face d'Israël irritèrent les juifs qui, au lieu de se convertir le crucifièrent. Peu s'en fallut que je n'aie subi le même sort à Lyon et à Paris comme tout le monde l'a su en son temps. Semblables à des juifs endurcis, les médecins ne se convertiront donc jamais; ou ne se convertiront-ils, comme eux, qu'à la fin du monde.» Pomme 1771, Tome II, 75. Repeated in: Pomme 1804, $75 \mathrm{f}$.

28 Pomme 1782, Avant-Propos, v. 
encounter scribes and Pharisees who will dispute my miracles; and that my kingdom is not of this world. Voltaire knew, as I do, that nulla est invidia supra invidia medicorum. ${ }^{29}$

Here, Voltaire's interpretation has been completely transformed. In the letter that Voltaire had addressed to Pomme, he affirmed that Pomme's kingdom was of this world, distancing medical practices from the notion of metaphysical power. Pomme rewrites Voltaire's phrase to read that his kingdom is not of this world, proclaiming a boundless authority. He uses Voltaire to appear as a divinely chosen healer and to grant himself the very powers that the philosopher had denounced. Rather than demystifying the mechanics of the convulsive body, Pomme mythologises his own medical practice. With the influence of the Church in decline, the religious lexicon becomes an open repertoire of metaphors, surrounding medicine with the air of authority it had lacked.

Voltaire's final mention of Pomme appears in a letter to a friend describing a "ferment" agitating Paris and the countryside. Reporting that two of his nephews are competing for a seat in the Parisian parliament, Voltaire writes:

It makes me laugh, and I laugh because I do not believe that our national illness is fatal. These symptoms are vertigos that should be cured by Mr. Pomme. ${ }^{30}$

For Voltaire the reference to Pomme serves to relativise and defuse tensions. By presenting political disputes as forms of pathology, Voltaire dismisses their importance. He casts them as uncontrollable movements that do not merit serious attention, more aptly described with the language of pathology than the language of reason. Presenting them as a malady suggests a temporary reaction, not endangering the French political system ${ }^{31}$.

29 «La nouvelle que l'on vous a donnée, M. le Marquis n'est pas sans fondement; parce qu'en effet je suis fou; et comment ne le serais-je pas, moi qui m'avise de vouloir corriger les médecins, en leur prêchant une morale qui contrarie leur croyance; c'est ici une nouvelle religion pour eux et vous savez ce qu'il en coûta aux apôtres pour avoir prêché celle de JésusChrist. D'après cela, il faut supposer ou que mon zèle est vraiment apostolique, ou que je suis fou. Voltaire m'écrivant de Fernay, pour avoir mon avis sur la maladie de Mme Racle, attaquée d'une perte de sang, qu'il comparait à l'hemorroisse de Jérusalem me disait: 〈Que quoiqu'il fut difficile à persuader il croyait à mon évangile; mais que je rencontrerais sur mon chemin des scribes et des pharisiens, qui contesteraient mes miracles; que mon royaume enfin n'était pas de ce monde.> Voltaire savait donc, et moi aussi, M. le Marquis que nulla est invidia supra invidia medicorum.» Pomme 1771, Tome II.

30 «Cela me fait rire, et je ris de tout ceci parce que je ne crois pas que cette maladie de la nation soit mortelle. Ses symptômes sont des vertiges qu'il faut faire guérir par M. Pomme." Voltaire, «Lettre à Louis-François-Armand du Plessis Duc de Richelieu à Ferney, 29 avril 1771», Voltaire 1986, 704.

31 In the same letter he writes later: "The fermentation is as strong in the provinces as in Paris, and will not likely produce but decrees that will not survive, and very useless protests without which France would be the fable of Europe.” [«La fermentation est aussi forte dans les provinces qu'à Paris, et ne produira vraisemblablement que des arrêtés qui ne subsisteront pas, et de protestations très inutiles sans quoi la France serait la fable de l'Europe.»] 
Around this time, Pomme's admirers follow the doctor's example in drawing upon religious metaphors. In November 1770, the Journal de Médecine publishes an article by a law professor named Caziot accusing Pomme of "unbearable arrogance" 32 . Pomme claims to immediately have responded with a letter to the editor, which, according to him, the Journal refuses to print. However, the Journal later agrees to publish an open letter addressed to Pomme by doctor France de Besançon, whom Pomme has recently cured:

You will find among your enemies, Sir, he [Mr. Caziot] who should be your apostle and the hero of your glory; that you should encounter among them this man who, by gratitude, should only eclipse them, this should surprise the entire Universe, our blood should run cold to see humanity so compromised and to see truthful sentiments so stifled. ${ }^{33}$

A few months later, the polemics surrounding Pomme return to the Journal de Médecine, when Doctor Zaugier describes Pomme's reported cure of Madame Pécauld as "a poorly written novel" ${ }^{34}$. Madame Pécauld herself signs a reply that proclaims that her cure "is entirely due" to Pomme. She insists:

I am pleased that you would give me another occasion to publish this news. Yes Sir, I have been healed of my convulsions and paralysis. I finally brave the illness and the enemies of the one who freed me. This is my profession of faith, which I will repeat whenever you should desire to contradict it..$^{35}$

Pomme also publishes this letter immediately afterwards, as part of the postscript to the 1771 edition of his treatise. France de Besançon and Madame Pécauld's metaphors of "apostle", "liberator" and "profession of faith" mirror Pomme's own phrases of preference.

From this moment on, Pomme incessantly calls upon theological references. He crafts them to transform the envisaging of medicine, projecting himself as a herald. Following his exchange with Voltaire, Pomme recalls and rewrites past successes for new editions of his treatise. His works come to be characterised by two predominant strategies: the use of metaphor and the rewriting of patient observations to create emblems for his therapies.

32 Journal de Médecine, Novembre 1770.

33 «Vous rencontrez, Monsieur, au milieu de vos ennemis, celui [M. Caziot] qui devrait être votre apôtre et le héros de votre gloire; que vous rencontriez au milieu d'eux celui qui, par reconnaissance, ne devrait paraître que pour les éclipser; cela doit étonner l'Univers entier: on ne saurait voir de sang froid et l'humanité compromise et les vrais sentiments étouffés.» Journal de Médecine, Supplément 1770, 5th notebook, 415, repeated in Pomme 1771, Postscriptum.

34 «Un roman mal ourdi», Journal de Médecine, Juillet 1770.

35 «J'aime bien que vous me procuriez une nouvelle occasion de la publier. Oui, Monsieur, je suis guérie de mes convulsions et de ma paralysie. Je brave enfin le mal et, qui plus est, les ennemis de mon libérateur. Voilà ma profession de foi, je la répéterai toutes les fois que vous paraîtrez vouloir la contredire.» Journal de Médecine, 1771. 
The doctor publishes edition upon edition in a weaving of metaphors that increasingly courts hyperbole. The most extravagant of metaphors, such as martyrdom and resuscitation, are repeated at regular intervals. The sixth edition of the treatise amasses these terms. "One speaks the truth at such a cost! And when one has the courage to declare oneself an apostle of the truth, should not one expect to become its martyr?" 36 Pomme reinterprets and reconnects his actions through religious imagining, and presents his entire practice through the prism of religion. He speaks of converting rather than convincing, his patients become lame rather than feverish, and he describes paralysis instead of numbness. Pomme recounts the suffering of those that did not heed his advice in a kind of catalogue of martyrs ${ }^{37}$ and he likens the pharmacists and doctors who oppose him to an impious sect. Pomme resuscitates dying patients, proclaims compassion for doctors who oppose his doctrine $^{38}$ and pronounces a mea culpa when recalling the patients he was unable to help at the beginning of his career ${ }^{39}$. Pomme writes that he

36 “Qu'il en coûte pour établir la vérité! et quand on a le courage de s'en déclarer l'apôtre, ne doit-on pas s'attendre à en être le martyr." Pomme 1804, 309.

37 "I could support this assertion with striking examples; but the image I presented would be too frightening, it would be a true martyrology." ["Je pourrois appuyer cette assertion par des exemples frappants; mais le tableau que je présenterois seroit trop effrayant, ce seroit un vrai martyrologue."] Pomme 1804, 14.

38 "P.S. I demand pardon from Mr. Bret, and offer him the kiss of peace that he once asked of me [...]. I ask that this reconcilation occurs in the presence of the same people who witnessed the first [...]. I finally implore the heavens with fervor so that they shine upon Mr. Bret, and that they favor this agreement for the good of humanity." [«P.S. Je demande très-sérieusement pardon à $\mathrm{M}$. Bret, et lui offre le baiser de paix qu'il m'a demandé une fois (...) je demande que cette réconciliation se fasse en présence des mêmes personnes qui furent les témoins de la première (...). J'implore enfin le ciel avec ferveur pour qu'il éclaire M. Bret, et qu'il favorise cet accord pour le bien de l'humanité.»] Bret 1806, 20.

39 "It is only after myself having committed many faults, that I recognized my error; and thus I believed it was my duty to publish. Like a charitable voyager who, wandering from the true path, retraces his steps, anxious to advise those who come after him that he had been mistaken, and to show them the true way." [ «Ce n'est enfin qu'après avoir moi-même commis bien des fautes, que j'ai reconnu mon erreur; et alors j'ai cru qu'il était de mon devoir de la publier. Semblable à ce voyageur charitable qui, s'étant égaré du vrai chemin, retourne sur ses pas, s'empresse d'avertir ceux qui viennent après lui qu'il s'étoit trompé, et leur montre la véritable route.»] Bret 1806, 81.

In the third edition of Réfutation de la doctrine médicale du Docteur Brown, médecin écossais, suivie d'un notice sur l'électricité, le galvanisme et le magnétisme, sous le rapport des maladies nerveuses in 1808, he blames the inexperience of his youth and claims: "I prepare myself to make amends for my faults; I will do so by preaching my example for the future." [«Je me dispose à réparer mes fautes; ce sera en prêchant d'exemple à l'avenir.»] Pomme $1808,67$.

In each edition Pomme adds newly won titles, first a doctor in medicine from the Université de Montpellier, he indicates later being a member of the Sociétés Académiques of Paris, Vaucluse and Marseille, a correspondent of the Celtic Academy and the Société de Médecine of Avignon. 
is stopped during his travels by sufferers on the roadside, begging for his care $^{40}$ and leaves his door open to "paupers" 41 . He speaks of his own words as "sacred truths" 42 . He repeatedly emphasises the loyalty of his patients they become his faithful.

Pomme frames his readers' reactions by colouring his experiences with theological images. The stylistic devices of Pomme do more than grant a literary and spiritual element to professional struggles over power and influence. They also function as levers with which to sway his audience. Pomme plays on their suggestive and emotional power to create unity around values such as humanity, devotion and sacrifice, and move his readers. His medical treatise gravitates towards the genre of the epideictic. The narrations of his experiences are forged in truth.

Pomme continues to publish until he is almost eighty years old, citing his age as evidence of his combat's righteousness. He writes that he is comforted by the attention his treatises have received: "Did I preach in the wilderness,

40 "On my return to Paris last year in the month of October, I was stopped several times in my journey, by the weak; if it were not by the master of the home, or the mistress, it was by postillions and other domestics who were on the pallet, again by the effect of quinine employed at the wrong time and with the greatest profusion; which indicated to me that the epidemic spread from Paris to Arles, and even to Nice, and that febrifuge expanded all around." [ «A mon retour de Paris, l'année passée au mois d'octobre, j'ai été arrêté en plusieurs endroits sur ma route, par des fébricitans; si ce n'étoit pas le maître de la poste, ou la maîtresse, c'étoit des postillons et autres domestiques qui étoient sur le grabat, par l'effet encore du quinquina employé à contre-temps et avec la plus grande profusion; ce qui m'a appris que l'épidémie s'étendoit depuis Paris jusqu'à Arles, et même jusqu'à Nice, et que partout on prodiguoit ce fébrifuge.»] Pomme 1804, 99.

41 "indigens": "That one portrays at present the critical circumstances in which I find myself in this moment, if not every day. The desperate patients address themselves to me and my door is open to all paupers; I acquire by their accounts the certitude that the doctor who treated them followed a route contrary to their recovery, and I hold the intimate conviction that all that can bring them back to life is in my own power. Should I give in or not to the solicitations of a family in tears, in the great interest inspired in me by so many unfortunate victims, to the sweet satisfaction only to do well towards others. Yes, without a doubt, indifference would be a weakness, and refusal to give counsel, a crime." [ «Qu'on se représente à présent les circonstances critiques dans lesquelles je me trouve en ce moment pour ne pas dire tous les jours. Les malades désespérés s'adressent à moi et ma porte est ouverte à tous les indigens; j'acquiers par leur récits la certitude que le médecin qui les a traités a suivi une route opposée à leur guérison, et j'ai l'intime conviction que celle qui peut seule les rappeler à la vie est seule en mon pouvoir. Dois-je céder ou non aux sollicitations d'une famille éplorée, au vif intérêt que m'inspirent tant de malheureuses victimes, à la douce satisfaction de faire uniquement le bien de mes semblables? Oui, sans doute; l'indifférence seroit une foiblesse, et le refus de donner mes conseils, un crime.»] Bret 1806, 15.

42 «saintes vérités»: "You doctors, you appear already offended, because the truths that I have announced to you so many times displease you. But this sacred truth always does well to hear; I believe that I have told it you in its entirety." [«Vous médecins, vous paroissez déjà offensés, parce que les vérités que je vous ai annoncées tant de fois vous déplaisent. Mais cette sainte vérité est toujours bonne à entendre; je crois vous l'avoir dite toute entière.»] Pomme 1804, 4. 
like John the Baptist? No, thank God, no. My anathema against the abuse of quinine woke the savants from their slumber regarding the most interesting aspect of clinical medicine." ${ }^{43} \mathrm{He}$ then pronounces what he calls his final "profession of faith":

Come what may, I shall proclaim this practice as long as I live. Not to harm you, but for the good of humanity ... I am now sheltered from the suspicions of rivalry. My motives are well known, my sentiments are above those of a hired scribe. I ask nothing of anyone, and declare to the Universe, that each time I was torn away from my garden to care for patients from near and far, I began by pitying them. For I am convinced that they were victims of the art [of medicine]. ${ }^{44}$

Across his ever-expanding repertoire of references, Pomme uses signs of accessibility and divine calling and signs of competence and recognition. These signs stretch across descriptions of individual cases, constituting a mythology of therapeutic deeds. As part of this expansion, Pomme appropriates religion's lexicon, history and role in society. He consecrates his work through the act of writing. Pomme attributes a transcendent value to his medical practice. He hypostasises medical discourse by raising it to the status of truth and faith.

The use of rhetorical figures is supplemented by narrative strategies in the rewriting of cases. Pomme's illustrations become emblems of his practice, seducing readers into supporting him and functioning as proof. The treatment of a patient named Lazarus Vidal offers a unique occasion for Pomme's talents as a writer. Here is the first version, contained in the 1765 edition of his treatise, before his exchange with Voltaire. It appears as a footnote and focuses on Pomme's professionalism in employing a variety of methods to save the patient:

Lazarus Vidal, a native of the village of la Baume in the principality of Orange, eighteen years of age, with a dry and slight temperament, was brought to the Hospital on July 9, 1763, by men of the countryside, who found him lying under a tree, without feeling or movement, such that they believed he was dead, I found this patient at the hospital at the hour of my visit. His pulse was very slow and concentrated, his jaw was so stiff and immobile that it was impossible to make him drink a single drop of water; this indicated that he required vesicatories. The next day there was no change. On the eleventh, he remained the same. On the twelfth, leeches and irritating enemas were applied, they were applied again on the thirteenth,

43 «Aurois-je prêché dans le désert comme Jean-Baptiste? Non grâce à Dieu, non. Mon anathème lancé contre l'abus du quinquina a réveillé les savants de leur assoupissement sur l'article le plus intéressant de la médecine clinique.» Pomme 1804, 101.

44 «Quoiqu'il en soit,j'éclairerai votre pratique tant que je vivrai, non pour vous nuire, mais pour le bien de l'humanité ... Je suis à l'abri d'une rivalité suspecte et intéressée. Mes motifs sont connus, mes sentiments sont au-dessus d'un écrivain stipendié. Je ne demande rien à personne, et je déclare à l'Univers, que toutes les fois que l'on vient m'arracher de mon jardin, pour des malades qui viennent de loin ou de près se confier à mes soins, je commence par les plaindre, parce que je suis assuré que ce sont des victimes de l'art.» Pomme 1804, 168. 
still without success. On the fourteenth, he developed a fever. Such a desperate case allowed for all sorts of experiments. Ice was applied to the patient's head. ${ }^{45}$

In this first version Pomme writes a detailed progression of the malady. He demonstrates the benefits of his intervention by describing the initial hopelessness of the case. Pomme presents his perseverance as a testament to his professionalism, recounting a succession of experiments as though illness could never outlast such devotion. Later, in the light of his final exchanges with Voltaire, Pomme's retelling of the story of Lazarus takes on new meaning. The tone is altered drastically in 1771, befitting a case ideal for such embellishment. Here is the tale of Lazarus as published in Nouveau recueil des pièces publiées pour l'instruction du procès que le traitement des vapeurs a fait naître parmi les médecins:

A poor beggar [Lazarus Vidal of Baume] was found dead under a tree, overexposed to the sun during a heat wave. He was sent to the Arles hospital and placed in a coffin. They were about to bury him, when I arrived for a visit to the hospital: I received the information necessary to understand his sad death; I examined the cadaver with the surgeon of the establishment. He saw the man's jaw to be in convulsion, after having been taut and immobile; from which I concluded that Lazarus was not dead, and that like the Lazarus of the Gospel, he could be brought back to life. The cadaver was thus plunged into a cold bath in my presence, and returned to life. ${ }^{46}$

Here, Pomme no longer concentrates on describing the patient's condition or the treatments applied. Now, the account is focused on staging Pomme's personal intervention. Pomme opts to forget the five days of fruitless efforts, and the patient is now instantly healed upon Pomme's initial treatment. What

45 «Lazare Vidal, natif du village de la Baume dans la principauté d'Orange, âgé de dix-huit ans, d'un tempérament maigre \& sec, fut apporté à l'Hôpital le 9 du mois de juillet 1763, par des hommes de campagne, qui le trouverent étendu sous un arbre, sans sentiment \& sans mouvement, de façon qu'on le crut mort, je trouvai ce malade à l'Hôpital à l'heure de ma visite. Son pouls étoit très-lent \& concentré, la mâchoire étoit si roide \& si immobile, qu'il fut toutà-fait impossible de lui faire avaler une seule goutte d'eau: ce qui me décida pour les vésicatoires. Le lendemain 10 du courant il n'y eut aucun changement. Le 11 tout fut de même. Le 12 on appliqua des sangsues, \& on donna des lavemens irritans; on y revint le 13, toujours infructueusement, \& le 14 la fièvre se mit de la partie. Un état aussi désespéré me permettoit toute sorte d'expériences. On appliqua de la glace sur la tête.» This note is displaced in different editions. It appears for the first time in the second edition of the treatise from 1765. Pomme 1765, 443f. footnote. It reappears in the Post-Scriptum to «Régime du Tempérament Vaporeux» (470-479). Pomme 1767, 475. It is repeated in the 1769 edition: «Réponse à l'Auteur du Journal des Savants», 443f. (see 438-450).

46 «Un pauvre mendiant [Lazare Vidal, du lieu dans la Baume dans le combat] est trouvé mort sous un arbre, exposé au soleil dans les chaleurs de la canicule. Il est transporté à l'hôpital d'Arles, il est placé dans la bierre. On allait l'ensevelir, lorsque j'arrive à l'hôpital pour faire ma visite: je prends les informations nécessaires pour découvrir les causes de cette triste mort; j'examine ce cadavre avec le chirurgien de la maison. Celui-ci trouve la machoire en convulsion puisque elle était roide et immobile; d'où je conclu que Lazare n'était pas mort, et que semblable à celui de l'évangile, il pouvait ressusciter. Ce cadavre fut plongé dans un bain froid en ma présence, il revint à la vie.» Pomme 1771, 309. 
had been a perilous lesson in 1765, becomes an immediate success in 1771 . There is an additional dramatic flair to the second account of the story, as the young patient is now lying in a coffin upon Pomme's arrival. The doctor is not treating a living patient - he is examining a cadaver. The cure thus resembles a miracle. With this rewriting Pomme places himself in the position of a savior, and the image of Christ emerges without equivocation. So as to stage the scene more suggestively, the "native of the village of la Baume" is recast as "a poor beggar".

A third retelling of this episode goes even further. After a purely oratorical interrogation into his methods, Pomme's 1804 Supplément au traité des affections vaporeuses des deux sexes ou maladies nerveuses repeats his list of preferred treatments. These therapies are reviewed summarily, emphasising Pomme's essential role in their application. To substantiate the value of bathing, Pomme again cites the case of Lazarus:

Must one cite the mute? [...] Must one cite the lame? [...] Must one resuscitate the dead? Lazarus Vidal of la Beaume [...] is found dead under a tree, overtaken by the power of the sun; he is brought to the hospital in Arles where I am working at the time. He is covered with a shroud and they are about to bury him. Then, the cadaver is plunged into a cold bath in my presence, with the mayor of Mejanes, dean of the school during the week, and the entire faculty of the hospital in attendance. And he comes back to life. ${ }^{47}$

Pomme employs the rhetorical device of enallage in this final narration. His employ of present tense in place of the past adds urgency to the scene. The account takes the form of a hypotyposis, with the cure seeming to take place before the readers' very eyes ${ }^{48}$. The scenographic quality of his account brings an element of performance to his medical intervention. The use of an ordinary bath without additional prescriptions centres attention on Pomme himself, and he now appears alone, apart from the other members of the faculty. Pomme's writing seeks the strength of instantaneous presence. His literary and rhetorical strategies enable a constant refashioning of therapies that are not particularly unique. By positioning water at the centre of his treatments, Pomme lends his therapies a symbolic reading. Water gives new

47 «Faut-il citer des muets? [...] Faut-il citer des paralytiques? [...] Faut-il enfin ressusciter un mort? Lazare Vidal du lieu de la Beaume, [...], fut trouvé étendu mort sous un arbre, exposé à l'ardeur du soleil; on l'apporte à l'hôpital d'Arles que je servois alors; il est en suaire, on va l'enterrer, ce cadavre est plongé dans un bain froid en ma présence, et celle de M. le M... de Méjanes, recteur en semaine, et de toute la faculté; il revient à la vie.» Pomme 1804, tome III, 76f.

$48 \mathrm{He}$ also speaks of the recovery of Madame the Marquise of Bezons after fifteen months of treatment in terms that are again suited for insistance upon the miraculous character of the event. "Madame la marquise de Bezons left her crutches, walked, ran on foot and by horse, and her recovery was radical." [«Madame la marquise de Bezons quitta les béquilles, marcha, courut à pied \& à cheval, \& sa guérison fut radicale.»] He later counts her among the "ressucitated" («ressuscitée»). Pomme 1771, 186, 188. 
life. And new life is procured by the presence of Pomme himself as much as by the bathing.

Pomme trumps Voltaire by citing the philosopher while disregarding his message, using his reputation, authority and celebrity, while reversing the implication of his reading. In a broad élan of writing, Pomme blends biblical references, invocations of the authority of the philosopher and espousal of his therapies.

In Pomme's work an affair of writing heralds a new practice of medicine, constructed through denomination and citation. In concentrating energy around the narration of treatments rather than descriptions of illness, Pomme emphasises his experience in daily encounters with patients, circumventing the image of doctors as savants lost amid antiquated books and obscure references. And unlike many of his colleagues, he does not advance abstract theories on the origin of maladies supported by only a handful of examples. Through this attention to the success of his treatments, Pomme professes devotion to the health of his patients. In return, he pressures patients to actively endorse his claims. Rather than combating illness alone, Pomme also appears in a struggle against his colleagues and their remedies. In professing his fervor, he portrays himself with a tendency for action more than reflection. His role is depicted as transformation above observation. His patients are not seen as victims of their bodies, nor are their illnesses viewed as judgments upon the excesses of their lifestyles. In Pomme's writings they are depicted as martyrs who have suffered at the hands of callous and greedy doctors. By mapping the discipline of medicine as a battlefield, Pomme suggests a dynamic of struggle and restitution. Such a war is waged in the space of writing, in the game of citations and on the field of language. By writing himself in a Christ-like image, Pomme aligns the therapeutic with the moral and the daily with the spiritual. The prestige of his personal practice lifts him above the customary position of a doctor in society. He is no longer a servant to aristocrats, catering to their every caprice. Through his writings Pomme projects himself into a dual mission to save the sick and enlighten his colleagues. The narratives of cases are forged in Pomme's own image, cementing his status in the minds of readers. His retellings draw them into a vertigo, in which Pomme emerges as a healer apart, his portrait reflecting across the mirror of every account. 


\section{Bibliography}

Anonyme, Réflexions d'un élève de M. Maria, professeur en affections vaporeuses, auteur \& Maître chirurgien-juré de Lyon sur les affections vaporeuses des deux sexes, par M. Pomme Fils, Docteur en Médecine, soi-disant professeur en affections vaporeuses, résident à Arles en Provence (Avignon 1763)

Arnaud, Sabine, «L'Art de vaporiser à propos, Pourparlers entre un médecin et une marquise vaporeuse», Dix-Huitième Siècle 39 (2007) 505-519

Aubert, François, «Pierre Pomme, médecin, récit familial», Bulletin des amis du vieil Arles (Arles 1998)

Barras, Vincent/Micheline Louis-Courvoisier (éds), La médecine des Lumières, tout autour de Tissot (Genève 2001)

Blackmore, Robert, A Treatise of the spleen and vapours, or hypocondriacal and hysterical affections, with three discourses on the nature and cure of the cholick, melancholy, and palsies (London 1725)

Bonnemant, Abbé, Extrait des singularités historiques, littéraire, politiques et sacrées et prophanes de la ville d'Arles (Manuscripts Library of the City of Arles)

Bret, Louis, Analyse comparée de quelques observations citées par M. Pomme, Dr en Médecine (Arles 1806)

Brockliss, Laurence/Colin Jones, The Medical World of Early Modern France (Oxford 1997)

Chaussinand-Nogaret, Guy, «Nobles médecins et médecins de cour au XVIII ${ }^{\mathrm{e}}$ siècle», Annales. Economies, Sociétés, Civilisations 32 (1977) 851-857

Chevalier, Jean-Baptiste, Mémoires et observations sur les effets des eaux de Bourbonne-lesBains, en Champagne dans les maladies hystériques \& chroniques (Paris 1772)

Cheyne, George, The English Malady (London 1733)

Chirac, Pierre/Jean-Baptiste Silva, Dissertations et consultations médicales (Paris 1740)

Cunningham, Andrew, "Sydenham versus Newton: The Edinburgh Fever Dispute of the 1690s, between Andrew Brown and Archibald Pitcairne", in:Willam F. Bynum/Vivian Nutton (eds), Theories of Fever from Antiquity to the Enlightment, Medical History Supplement no. 1 (London 1981) 71-98

Duden, Barbara, Geschichte unter der Haut. Ein Eisenacher Arzt und seine Patientinnen um 1730 (Stuttgart 1987)

Eynard, Charles, Essai sur la vie de Tissot, contenant des lettres inédites de Tronchin, Voltaire, Haller, Zimmermann, Rousseau, Bonnet, Stanislas Auguste II, Napoléon Bonaparte (Lausanne 1839)

Findlen, Paola, "Controlling the experiment: rhetoric, court patronage and the experimental method of Francesco Redi (1626-1697)", History of science 31 (1993) 35-64

Harley, David, "Honour and Property: The Structure of Professional Disputes in Eighteenth Century English Medicine", in: Andrew Cunningham/Roger French (eds), The Medical Enlightenment of the Eighteenth Century (Cambridge 1990) 138-164

- "Rhetoric and the Social Construction of Sickness and Healing", Social History of Medicine 12 (1999) 407-435

Hunauld, Pierre, «Dissertation sur les vapeurs et les pertes de sang (1756)», in: Sabine Arnaud (éd.), La philosophie des vapeurs (Paris 2009)

Jordanova,Ludmilla, Defining Features: Scientific and Medical Portraits 1660-2000(London 2000)

- The Popularization of Medicine: Tissot on Onanism", in: Ludmilla Jordanova, Nature Displayed, Gender, Science and Medicine: Essays (London 1999)

Lieutaud, Joseph, Précis de la médecine pratique (Paris ${ }^{3} 1781$ )

Lockwood, Dean Putnam, Ugo Benzi: Medieval Philosopher and Physician (1376-1439) (Chicago 1951)

Nance, Brian, Turquet de Mayerne as Baroque Physician: the Art of Medical Portraiture (Amsterdam/New York 2001)

Pomme, Pierre, Traité des affections vaporeuses des deux sexes: ou Maladies nerveuses, vulgairement appelées maux de nerfs (Lyon 1760, 1765, 1769, 1771, Paris 1782, 1798-1799, 1804)

- Sopra le affezioni vaporese, Opera del Signore Pomme, figlio (Naples 1765)

- Traité des affections vaporeuses des deux sexes: Où l'on a tâché de joindre à une théorie solide une pratique sûre, fondée sur des observations (Lyon 1767) 
- Nouveau recueil des pièces publiées pour l'instruction du procès que le traitement des vapeurs a fait naître parmi les médecins, dans lequel on trouve la réponse à toutes les objections que l'on a faites contre la méthode humectante, \& des nouvelles observations pratiques qui en démontrent la sûreté (Paris 1771)

- Abhandlung von den hysterisch und hypochondrischen Nervenkrankheiten beider Geschlechter oder von den Vapeurs (Breslau 1775)

- Nuevo Método para curar flatos, hypocondria, vapores y ataques hystericos de las mujeres de todos estados: y en todo estado, con el qual los enfermos podrán por sí cuidar de su salud en falta de medico que les dirija (Madrid 1776, 1786, 1794)

- A Treatise on hysterical and hypochondriacal diseases: in which a new and rational theory is proposed, and a cure recommended (London 1777)

- Supplément au traité des affections vaporeuses des deux sexes ou maladies nerveuses, dans lequel on trouve 1. Mémoire et observations cliniques sur l'abus du quinquina 2. Réfutation de la doctrine médicale de Brown 3. Notice sur l'électricité, le galvanisme et le magnétisme (Paris An XII, 1804)

- Réfutation de la doctrine médicale du Docteur Brown, médecin écossais, suivie d'une notice sur l'électricité, le galvanisme et le magnétisme, sous le rapport des Maladies nerveuses, $3^{\mathrm{e}}$ éd. corrigée et augmentée (Arles 1808)

Porter, Roy (ed.), The Popularization of Medicine, 1650-1850 (London 1992)

Pressavin, Jean-Baptiste, Nouveau Traité des vapeurs ou traité des maladies des nerfs dans lequel on développe les vrais principes des vapeurs (Lyon 1770)

Ramsey, Matthew, Professional and Popular Medicine in France, 1770-1830. The Social World of Medical Practice (Cambridge 1988)

Raulin, Joseph, Traité des affections vaporeuses du sexe avec l'exposition de leurs symptômes ... \& la méthode de les guérir (Paris 1758)

Roche, Daniel, «Talents, raison et sacrifice», Annales. Economies, Sociétés, Civilisations 32 (1977) 866-886

Rostaing, Réflexions sur les affections vaporeuses ou examen du traité des vapeurs des deux sexes (Amsterdam ${ }^{3} 1768$ )

Shapin, Steven, A Social History of Truth: Civility and Science in Seventeenth-Century England (Chicago 1994)

Siraisi, Nancy, "Giovanni Argenterio and sixteenth-century medical innovation: between princely patronage and academic controversy", Osiris 6 (1990) 161-180

- "G. Cardano and the art of medical narrative", Journal of the History of Ideas 52 (1991) 581-602

Tribby, Jay, "Cooking (with) Clio and Cleo: eloquence and experiment in seventeenth-century Florence", Journal of the History of Ideas 52 (1991) 417-423

Vieussens, Raymond de, Réponse du Sieur Vieussens, docteur en médecine, de la Faculté de Montpellier à trois lettres imprimées du Sieur Chirac, Professeur en Médecine de l'Université de la même ville (Montpellier 1698)

Vila, Anne C., "Sex, procreation, and the scholarly life from Tissot to Balzac", Eighteenth-Century Studies 35 (2002) 239-246

Voltaire, Correspondance, Euvres Complètes, Tome 19, 67 (Paris 1986)

- Questions sur l'Encyclopédie, Dictionnaire philosophique, in: Euvres Complètes, édité par Beuchot, Volume 18, tome II, $4^{\mathrm{e}}$ partie (Paris 1878)

- Correspondance avec les Tronchin, édité par André Delattre (Paris 1950)

Wenger, Alexandre, La fibre littéraire, le discours médical sur la lecture au XVIII siècle (Genève 2007)

- «Le 〈procès Pierre Pomme»: légitimité professionnelle et violence polémique dans une querelle médicale du XVIII ${ }^{\mathrm{e}}$ siècle», in: Vincent Azoulay et al., Le mot qui tue, les violences intellectuelles de l'Antiquité à nos jours (Seyssel 2009) 